\title{
SUPERVISI AKADEMIK INDIVIDUAL SEBAGAI UPAYA PENINGKATAN KINERJA GURU MATA PELAJARAN PAK DI SMK IMMANUEL KOTA MEDAN
}

\author{
Sontur Saragih \\ Pengawas Guru PAK Tingkat SMP-SMA Kankemenag Kota Medan \\ Roimanson Panjaitan \\ Dosen Jurusan Pendidikan Agama Kristen STAKN Kupang \\ Penulis Korespondensi: ryans_110983@yahoo.co.id
}

\begin{abstract}
Abstrak
Penelitian ini bertujuan untuk mengetahui apakah suvervisi akademik individual dapat meningkatkan kinerja guru PAK. Penelitian ini dilaksanakan di SMK Immanuel Medan yang terletak di jalan Gatot Subroto, Medan, Sumatera Utara dan berlangsung selama semester gasal tahun 2016 dengan melibatkan 5 orang guru PAK sebagai responden dengan menggunakan metode tindakan sekolah yang terdiri dari beberapa tahapan, yakni mulai dari tahapan perencanaan, pelaksanaan, evaluasi dan tahapan refleksi. Sebelum dilakukan tindakan diperoleh bahwa pengamatan Indeks Kinerja Guru PAK Secara Kumulatif tahap Pra-Observasi terlihatbahwa rata-rata nilai indeks kinerja guru PAK pada kategori Cukup Baik. Pada pengamatan dari pra-observasi hingga tindakan siklus I indikator kinerja guru PAK dalam merencanakan pembelajaran meningkat menjadi baik (empat orang) dan satu orang tidak mengalami perubahan. Pada indikator melaksanakan pembelajaran, meningkat menjadi baik (1 orang). Demikian juga pada indikator mengevaluasi pembelajaran, meningkat menjadi baik (4 orang) dan 1 orang tidak mengalami perubahan. Namun karena indicator keberhasilan dalam penelitian ini adalah dilihat dari meningkatnya kinerja guru PAK sebagai perencana, pelaksana dan mengevaluasi hasil pembelajaran dengan seperangkat indikatornya berada pada kategori Sangat Baik, maka penelitian dilanjutkan pada siklus II. Dari hasil pengamatan dari pada siklus II mengalami peningkatan. Pada siklus I, seluruh orang responden semua memiliki rata-rata memiliki nilai pada kategori Baik pada seluruh indikator; sedangkan setelah dilakukan tindakan pada siklus II hasilnya menjadi "bahwa keseluruhan indikator kinerja guru PAK, yakni merencanakan, melaksanakan dan mengevaluasi pembelajaran, rata-rata berada berada pada kategori sangat baik; dengan demikian disimpulkan bahwa suvervisi individual dapat meningkatkan kinerja guru PAK.
\end{abstract}

Kata Kunci: Pengawas, Suvervisi Individual, Kinerja Guru PAK 


\section{PENDAHULUAN}

Pendidikan pada dasarnya diartikan sebagai upaya membudayakan manusia atau memanusiakan manusia. Oleh sebab itu pendidikan merupakan upaya strategis untuk mencerdaskan kehidupan bangsa dan merupakan aspek yang sangat diperlukan guna meningkatkan mutu bangsa secara menyeluruh. ${ }^{1}$ Dengan demikian jelas bahwa peningkatan mutu pendidikan ditentukan oleh kesiapan sumber daya manusia yang terlibat dalam proses pendidikan. Dalam hal ini, guru merupakan salah satu faktor penentu tinggi rendahnya mutu hasil pendidikan mempunyai posisi strategis maka setiap usaha peningkatan mutu pendidikan perlu memberikan perhatian besar kepada peningkatan guru baik dalam segi jumlah maupun mutunya. Disebut demikian karena guru yang langsung bersinggungan dengan peserta didik, untuk memberikan bimbingan yang akan menghasilkan tamatan yang diharapkan. ${ }^{2}$ Sebab, guru merupakan sumber daya manusia yang menjadi perencana, pelaku dan penentu tercapainya tujuan pendidikan. Untuk itu dalam menunjang kegiatan guru, diperlukan iklim sekolah yang kondusif dan hubungan yang baik antar unsur-unsur yang ada di sekolah antara lain kepala sekolah, guru, tenaga administrasi dan siswa. Serta hubungan baik antar unsur-unsur yang ada di sekolah dengan orang tua murid maupun masyarakat. Dalam pencapaian tujuan pembelajaran kinerja guru merupakan hal yang sangat menentukan.

Pendidikan Agama Kristen atau yang sering disebut dengan istilah PAK dalam kedudukannya sebagai bagian dari sistem pendidikan nasional, juga memiliki tujuan tersendiri. ${ }^{3}$ Karena itu keberhasilan untuk mencapai tujuan PAK juga sangat ditentukan oleh keberadaan guru PAK. Guru PAK mengemban tanggugjawab yang bertujuan membantu peserta didik berkembang untuk memasuki persekutuan iman dengan Tuhan Yesus sehingga menjadi pribadi yang bertanggungjawab baik kepada Allah maupun kepada manusia. ${ }^{4}$ Oleh

${ }^{1}$ Bandingkan dengan Tujuan Pendidikan Nasional sebagaimana tercantum dalam UU No. 20 Tahun 2003 Tentang Sistem Pendidikan Nasional, Bab 2 Pasal 3.

${ }_{2}$ Pada bagian pendahuluan, Direktorat Jenderat Peningkatan Mutu Pendidik dan Tenaga Kependidikan menguraikan bahwa: "Guru merupakan elemen kunci dalam sistem pendidikan, khususnya di sekolah. Semua komponen lain, mulai dari kurikulum, sarana-prasarana, biaya, dan sebagainya tidak akan banyak berarti apabila esensi pembelajaran yaitu interaksi guru dengan peserta didik tidak berkualitas. Semua komponen lain, terutama kurikulum akan "hidup" apabila dilaksanakan oleh guru." Selengkapnya dapat dilihat dalam Buku Penilaian Kinerja Guru (Jakarta: Departemen Pendidikan Nasional, 2008), 1.

${ }^{3}$ Lihat Peraturan Pemerintah No 55. Tahun 2007 Tentang Penyelenggaraan Pendidikan Agama dan Pendidikan Keagamaan

${ }^{4}$ E.G. Homrighausen dan I.H. Enklaar, Pendidikan Agama Kristen, (Jakarta: BPK gunung Mulia, 1985), 180-181. 
sebab itu menjadi guru PAK, selain harus memiliki kecakapan (kompetensi) juga dituntut untuk memiliki kinerja yang baik. Sebab tugas yang diembannya bukan hanya pekerjaan yang membutuhkan sikap profesionalisme semata, namun juga berkaitan erat dengan pertanggungjawannya sebagai mitra Allah dalam mewujudkan visiNya bagi peserta didik. ${ }^{5}$ Sebagai seorang yang harus profesional guru PAK haruslah kreatif dan cakap dalam melakukan pekerjaannya. Sebagaimana Yesus Sang Guru Agung, yang kreatif menggunakan berbagai metode dalam mengajar. ${ }^{6}$ Dengan demikian Guru PAK haruslah memiliki kualifikasi yang mendasar dalam dirinya mengenai profesi yang dimiliki sebagai seorang pendidik, dan juga mampu mengualifikasikan dirinya sendiri untuk meraih standar keguruan yang ia miliki, serta memiliki kualifikasi rohani sebagai bentuk tanggungjawab untuk memperkanalkan Tuhan Yesus sebagai juruselamat kepada orang lain, yang secara khusus dalam hal ini adalah nara didik. Karena itu menjadi guru PAK harus mampu menunjukkan kinerja yang baik.

Kinerja guru PAK berkaitan erat dengan aspek kompetensi, seperti profesional, kepribadian, pedagogik dan sosial yang dimilikinya. ${ }^{7}$ Selain itu kinerja guru PAK juga erat kaitannya dengan perangkat proses untuk menciptakan pemahaman bersama mengenai apa yangharus dicapai, bagaimana hal itu harus di capai serta bagaimana mengatur orang dengan cara meningkatkan kemungkinan tercapainya tujuan. ${ }^{8}$ Tentang hal itu ada beberapa aspek perilaku yang tampak dalam unsur kinerja guru PAK. Sebagaimana yang diungkapkan Mitchell dalam Sedarmayanti menyatakan kinerja meliputi lima aspek, yaitu: quality of work; promptness; initiative;capability; dan communication. ${ }^{9}$ Kelima aspek tesebut dapat dijadikan ukuran dalam mengadakan pengkajian tingkat kinerja seseorang. Sedangkan Robins, menyatakan: "kinerja adalah gerakan, perbuatan, pelaksanaan, kegiatan, atau tindakan yang diarahkan untuk mencapai tujuan atau target. ${ }^{10}$ Dengan demikian hal ini berarti kinerja seseorang dapat dilihat dari proses bagaimana seseorang dapat melaksanakan pekerjaannya. Jika tujuan yang akan dicapai adalah tentang tujuan pembelajaran PAK, maka yang menjadi indikator

${ }^{5}$ Ibid.

${ }^{6}$ Ruth Kadarmanto, Tuntunlah Ke Jalan Yang Benar, (Jakarta: BPK. Gunung Mulia, 1999), 98.

${ }^{7}$ UU No. 14 Tahun 2005 Tentang Guru dan Dosen, Bab. IV, Pasal 10 Ayat 1.

8 Bachtiar Hasan, Perencanaan Pengajaran Bidang Study, (Bandung: Pustaka Ramadhan, 2004), 17.

9 Sedarmayanti, Manajemen Sumber Daya Manusia, Bandung: Refika Aditama, 2001), 51.

${ }^{10}$ Stephen P. Robbin, Perilaku Organisasi, (Jakarta: Indeks, 1996), 260. 
sesorang guru dalam mewujudkan kinerja yang baik dilihat dari tuntas atau tidaknya tujuan pembelajaran PAK yang akan dicapai.

Memang, baik atau tidaknya kinerja seorang guru dalam melaksanakan tugas dan pekerjaannya sangat dipengaruhi oleh beragai faktor. ${ }^{11}$ Salah satu faktor yang mempengaruhi faktor kinerja guru PAK adalah faktor supervisi atau pengawasan terhadap pelaksanaan tugas pengajaran yang dilakukan oleh guru PAK. Sebagaimana diungkapkan oleh Sahertian bahwa dalam proses pendidikan, pengawasan atau supervisi merupakan bagian tidak terpisahkan dalam upaya peningkatan prestasi belajar dan mutu sekolah. ${ }^{12}$ Oleh sebab itu tugas pengawasan perlu dilakukan. Sebab menurut Depdiknas masih banyak guru yang masih tertutup soal kinerjanya di sekolah. ${ }^{13}$ Karena itu, penilaian kinerja guru merupakan suatu hal yang perlu mendapat perhatian serius khususnya oleh pengawas PAK.

Dalam melakukan penilaian kinerja guru PAK, seorang pengawas seyogyanya memiliki kemampuan untuk: (1) memahami ruang lingkup variabel yang hendak dinilai, terutama kompetensi profesional guru, (2) memiliki standar dan/ atau menyusun instrumen penilaian, (3) melakukan pengumpulan dan analisis data, dan (4) membuat judgement atau kesimpulan akhir kinerja guru. Dengan demikian, suvervisi yang dilakukan seorang pengawas sangat strategis terhadap capaian kinerja yang ditunjukkan oleh guru PAK sesuai dengan wewenang yang diberikan kepadanya. ${ }^{14}$ Akan tetapi berdasarkan tinjauan dan identifikasi yang dilakukan tentang persoalan-persoalan yang berkaitan dengan tugas kepengawasan dan kinerja guru PAK masih ditemukan beberapa pokok-pokok permasalahan tentang kinerja guru PAK, antara lain: 1) kinerja guru

${ }^{11}$ Mahmudi dalam uraiannya menjelasakan bahwa Faktor-faktor tersebut dapat berupa antara lain: tingkat pendidikan guru, supervisi pengajaran, program penataran, iklim yang kondusif, sarana dan prasarana, kondisi fisik dan mental guru, gaya kepemimpinan kepala sekolah, jaminan kesejahteraan, kemampuan manajerial kepala sekolah dan lain sebagainya. Lihat Manajemen Kinerja Sektor Publik, (Yogyakarta: Unit Penerbit dan Percetakan. Sekolah Tinggi Ilmu Manajemen YKPN, 2007), 20.

12 P.A. Sahertian, Konsep Dasar \& Teknik Supervisi Pendidikan, (Jakarta: Bineka Cipta, 2000), 19.

13 Dalam BukuPenilaian Kinerja Guru, (Jakarta: Departemen Pendidikan Nasional, 2008), 1.

${ }^{14}$ Wewenang yang diberikan kepada pengawas meliputi: (1) memilih dan menentukan metode kerja untuk mencapai hasil yang optimal dalam melaksanakan tugas dengan sebaik-baiknya sesuai dengan kode etik profesi, (2) menetapkan tingkat kinerja guru dan tenaga lainnya yang diawasi beserta faktor-faktor yang mempengaruhinya, (3) menentukan atau mengusulkan program pembinaan serta melakukan pembinaan. Nana Sudjana, Standar Mutu Pengawas. (Jakarta: Depdiknas, 2006), 6 . 
PAK yang berkaitan dengan tugas perencanaan, pengelolalan pembelajaran dan penilaian hasil belajar siswa, 2) pelaksanaan tugas dan fungsi pengawas MGMP PAK di Sekolah? dan 3) keterkaitan antara severvisi akademik yang dilakukan oleh pengawas MGMP PAK dengan peningkatkan kinerja guru PAK di sekolah. Oleh sebab itu untuk menjawab beberapa identifikasi permasalahan tersebut perlu dilakukan sebuah penelitian untuk melihat apakah pelaksanaan tugas dan fungi pengawas yang berkaitan dengan suvervisi akademik dapat meningkatkan kinerja guru PAK, dan kali ini penelitian dilaksanakan di SMK Immanuel Medan, Prov. Sumatera Utara sebagai salah satu sekolah binaan peneliti sebagai pengawas guru mata pelajaran PAK.

\section{PEMBAHASAN}

\section{Hakikat Pengawas Sekolah}

Menurut Amiruddin dkk, pengawas adalah salah satu tenaga pendidikan yang bertugas memberikan pengawasan agar guru, kepala sekolah dan personil lainnya di sekolah dapat menjalankan tugasnya dengan baik. ${ }^{15}$ Sedangkan menurut Arikunto pelaku supervisi dengan pengertian baru tentang supervisi yaitu semua upaya dalam rangka untuk meningkatkan kualitas pembelajaran, maka yang menjadi pelaku supervisi bukan lagi hanya pengawas dan kepala sekolah, tetapi beberapa pihak yang terkait dengan kegiatan pembelajaran. ${ }^{16}$ Dalam hal ini kedudukan pengawas dan kepala sekolah bukan berarti tergeser, tetapi justru menjadi semakin penting. Pengawas dan kepala sekolah tetap menjadi penanggung jawab utama kegiatan supervisi, tetapi data yang diberikan oleh pihak-pihak lain memperkaya bahan dasar untuk pembinaan. Dengan demikian pengawas merupakan tenaga kependidikan yang bertugas memberikan pengawasan agar tenaga kependidikan (guru, kepala sekolah, personil lainnya di sekolah) dapat menjalankan tugasnya dengan baik.

Dalam melaksanakan tugasnya pengawas bertugas melakukan pengawasan dengan mendeterminasikan apa yang telah dilaksanakan maksudnya mengevaluasi prestasi kerja dan apabila perlu menerapkan tindakan-tindakan korektif sehingga hasil pekerjaan sesuai dengan rencana pengawasan, merupakan afiktifitas untuk menentukan,

${ }^{15}$ Amiruddin dkk, Manajemen Pengawasan Pendidikan, (Jakarta: Quantum Teaching, 2006), 2.

${ }^{16}$ Suharsimi Arikunto, Dasar-dasar Supervisi, (Jakarta: Rineka Cipta, 2006), 89. Sedangkan berdasarkan Kep.Mendikbud RI Nomor 020/U/1998 Pengawas sekolah adalah pegawai negeri sipil yang diberi tugas, tanggung jawab, dan wewenang secara penuh oleh pejabat yang berwenang untuk melakukan penilaian dan pembinaan dari segi teknis pendidikan dan administratif pada satuan pendidikan pra sekolah, sekolah dasar, dan sekolah menengah. 
mengoreksi penyimpangan-penyimpangan penting terhadap aktifitasaktifitas yang direncanakan. ${ }^{17}$ Hal ini juga ditegaskan dalam keputusan Menteri Pendidikan dan Kebudayaan Republik Indonesia nomor 020/U/1998 Bab I huruf C disebutkan: Tugas, tanggung jawab dan wewenang Pengawas adalah melakukan pengawasan pendidikan di sekolah dengan melaksanakan penilaian dari pembinaan dari segi teknis pendidikan dan administrasi.

Dari uraian di atas dapat disimpulkan bahwa pengawas bertugas mengembangkan kurikulum sekolah, melakukan pembinaan kepada guru dan staf sekolah, pembinaan pengelolaan sarana dan prasarana sekolah, serta bertugas mengembangkan hubungan sekolah dengan masyarakat.

\section{Supervisi Akademik Individual}

\section{Pengertian Suvervisi Individual}

Supervisi akademik individual adalah salah satu bentuk dan teknik pelaksanaan suvervisi. Glickman mendefinisikan supervisi akademik sebagai "serangkaian kegiatan membantu guru mengembangkan kemampuannya mengelola proses pembelajaran, juga berusaha untuk membantu guru mengembangkan kemampuannya mencapai tujuan pembelajaran". ${ }^{18}$ Sedangkan Banun Muslim mendefinisikan supervisi akademik sebagai serangkaian usaha pemberian bantuan kepada guru dalam bentuk layanan profesional yang diberikan oleh supervisor (kepala sekolah, penilik sekolah dan pembina lainnya) guna meningkatkan mutu proses dan hasil belajar mengajar". ${ }^{19}$ Disebut individual karena dalam pelaksanaannya tugas pelaksanaan suvervisi akademik ini dilaksananakan secara individual oleh pengawas. Dengan demikian dapat disimpulkan bahwa supervisi akademik individual adalah usaha dari seorang pengawas sekolah dalam memimpin guru-guru dan petugas lainnya dalam memperbaiki pengajaran, termasuk menstimulir, menyeleksi pertumbuhan jabatan dan perkembangan guru-guru dan merevisi tujuan-tujuan pendidikan,

${ }^{17}$ Winardi, Azas-azas Manajemen (Bandung: Alumni Bandung, 1979), 22. Kemudian ditegaskan juga dalam Adapun wewenang pengawas menurut Keputusan Menpan No. 0322 Tahun 1996 dan No. 38 tahun1996 itu mencakup: (1) memilih dan menentukan metode kerja untuk mencapai hasil yang optimal dalam melaksanakan tugas dengan sebaik-baiknya sesuai dengan kode etik profesi, (2) menetapkan tingkat kinerja guru dan tenaga lain yang diawasi serta faktor-faktor yang mempengaruhi serta (3) menentukan dan atau mengusulkan program pembinaan serta melakukan pembinaan.

${ }^{18}$ Glickman, Supervision of Instruction (Boston: Ally and Bacon Inc, 1995), 26.

19 Sri Banun Muslim, Supervisi Pendidikan Meningkatkan Kualitas Profesionalisme Guru (Bandung: Penerbit Alfabeta, 2009), 41. 
bahan-bahan pengajaran dan metode mengajar dan evaluasi pengajaran.

Tujuan dari supervisi pendidikan adalah memperkembangkan situasi belajar dan mengajar yang lebih baik. Konkeritnya, tujuan supervisi akademik secara operasional dapat dikemukakan beberapa adalah untuk: guru melihat dengan jelas tujuan-tujuan pendidikan, membantu guru dalam membimbing pengalaman belajar murid-murid, membantu guru dalam menggunakan sumber-sumber pengalaman belajar, membantu guru dalam menggunakan metode-metode dan alatalat pelajaran moderen, membantu guru dalam memenuhi kebutuhan belajar murid-murid, membantu guru dalam hal menilai kemajuan murid-murid dan hasil pekerjaan guru itu sendiri, membantu guru dalam membina reaksi mental atau moral kerja guru dalam rangka pertumbuhan pribadi dan jabatan mereka, membantu baru di sekolah sehingga mereka merasa gembira dengan tugas yang diperolehnya, membantu guru agar lebih mudah mengadakan penyesuaian terhadap masyarakat dan cara-cara menggunakan sumber-sumber masyarakat, membantu guru agar waktu dan tenaga tercurahkan sepenuhnya dalam pembinaan sekolahnya. ${ }^{20}$ Dengan demikian jelaslah bahwa pelaksanaan supervisi akademik bertujuan untuk melihat bagaimana keterlaksanaan dari suatu rencana dengan apa yang terjadi dikelas dalam proses belajar mengajar. Pelaksanaan supervisi dibagi menjadi dua golongan yaitu teknik perseorangan dan teknik kelompok.

Adapun pendekatan supervisi akdemik menurut Sahertian dapat dilakukan dengan tiga cara yaitu: pendekatan direktif, nondirektif, dan kolaboratif. ${ }^{21}$ Pendekatan direktif (langsung) adalah cara pendekatan terhadap masalah yang bersifat langsung. Di sini supervisor memberikan arahan langsung. Sudah tentu pengaruh perilaku supervisor lebih dominan. Oleh karena guru ini mengalami kekurangan, maka perlu diberikan rangsangan agar ia bisa bereaksi. supervisor dapat menggunakan penguatan (reinforcement) atau hukuman (punishment).

Adapun pendekatan tidak langsung (non-direktif) adalah cara pendekatan terhadap permasalahan yang sifatnya tidak langsung. Perilaku supervisor tidak secara langsung menunjukkan permasalahan, tapi ia terlebih dahulu mendengarkan secara aktif apa yang dikemukakan guru-guru. Ia memberi kesempatan sebanyak mungkin kepada guru untuk mengemukakan permasalahan yang mereka alami.

${ }^{20}$ Piet. A. Sahertia, Prinsip dan Tehnik Supervisi Pendidikan (Surabaya: Usana Offset Printing, 1981), 24.

${ }^{21}$ Piet A. Sahertian, Prinsip dan Tehnik Supervisi Pendidikan, (Surabaya: Usaha Nasional, 2000), 44-52. 
Guru mengemukakan masalahnya supervisor mencoba mendengarkan, memahami, apayang dialami guru-guru. Pada pendekatan ini baik supervisor maupun guru bersama-sama, bersepakat untuk menetapkan struktur, proses dan kriteria dalam melaksanakan proses percakapan terhadap masalah yang dihadapi guru. Dengan demikian pendekatan dalam supervisi berhubungan pada dua arah. Dari atas kebawah dan dari bawah keatas (bottom up dan top down). Perilaku supervisor adalah sebagai berikut: menyajikan, menjelaskan, mendengarkan, memecahkan masalah, dan negosiasi.

\section{Teknik Suvervisi Individual}

Teknik supervisi perseorangan adalah pelaksanaan supervisi yang diberikan kepada guru tertentu yang mempunyai masalah khusus dan bersifat perorangan. Pengawas di sini hanya berhadapan dengan seorang guru yang dipandang memiliki persoalan tertentu. Teknikteknik supervisi yang dikelompokkan sebagai teknik individual meliputi: kunjungan kelas, observasi kelas, pertemuan individual, kunjungan antarkelas, dan menilai diri sendiri.

Pertama, mengadakan kunjungan kelas. Pelaksanaan kunjungan kelas adalah bentuk kunjungan sewaktu-waktu yang dilakukan oleh seorang pengawas untuk melihat atau mengamati seorang guru yang sedang mengajar. Tujuannya untuk mengobservasi bagaimana guru mengajar, apakah sudah memenuhi syarat-syarat deduktis atau metodik yang sesuai, dengan kata lain untuk melihat apa kekurangan atau kelemahan yang perlu diperbaiki. Pada tahap ini pengawas akan mensupervisi guru saat melakukan kegiatan pembelajaran di dalam kelas, gunanya untuk mengetahui bagaimana kemampuan seorang guru dalam menyampaikan materi di kelas. Pengawas yang efektif dan mengisi waktu luangnya untuk mengamati dan melihat guru di dalam kelas, bagaimana cara untuk meningkatkan kemampuan guru dalam menyampaikan materi pelajaran baik secara seni atau secara ilmu pengetahuan.

Kedua, mengadakan observasi kelas. Observasi kelas adalah teknik observasi yang dilakukan oleh pengawas terhadap proses pembelajaran yang sedang berlangsung. Tujuannya adalah untuk memperoleh data seobyektif mungkin mengenai aspek-aspek dalam situasi belajar mengajar, kesulitankesulitan yang dihadapi oleh guru dalam usaha memperbaiki proses belajar mengajar. Secara umum, aspek-aspek yang diamati selama proses pembelajaran yang sedang berlangsung adalah: (1) usaha-usaha dan aktivitas guru-siswa dalam proses pembelajaran, (2) cara penggunaan media pengajaran, (3) reaksi mental para siswa dalam proses belajar mengajar (4) keadaan media pengajaran yang dipakai dari segi materialnya. 
Ketiga, pertemuan individual. Pertemuan individual adalah satu pertemuan, percakapan, dialog, dan tukar pikiran antara pembina atau pengawas guru, guru dengan guru, mengenai usaha meningkatkan kemampuan profesional guru. Tujuannya adalah: (1) memberikan kemungkinan pertumbuhan jabatan guru melalui pemecahan kesulitan yang dihadapi; (2) mengembangkan hal mengajar yang lebih baik; (3) memperbaiki segala kelemahan dan kekurangan pada diri guru; dan (4) menghilangkan atau menghindari segala prasangka yang bukan bukan.

Keempat, kunjungan antarkelas. Kunjungan antarkelas dapat juga digolongkan sebagai teknik supervisi secara perorangan. Guru dari yang satu berkunjung ke kelas yang lain dalam lingkungan sekolah itu sendiri. Dengan adanya kunjungan antarkelas ini, guru akan memperoleh pengalaman baru dari teman sejawatnya mengenai pelaksanaan proses pembelajaran, pengelolaan kelas, dan sebagainya.

Kelima, menilai diri sendiri. Menilai diri sendiri merupakan satu teknik individual dalam supervisi pendidikan. Penilaian diri sendiri merupakan satu teknik pengembangan profesional guru. ${ }^{22}$ Penilaian diri sendiri memberikan informasi secara obyektif kepada guru tentang peranannya di kelas dan memberikan kesempatan kepada guru mempelajari metoda pengajarannya dalam mempengaruhi murid. ${ }^{23}$ Semua ini akan mendorong guru untuk mengembangkan kemampuan profesionalnya.

\section{Kinerja Guru PAK}

\section{Pengertian Kinerja Guru PAK}

Sebagai seorang profesional tugas guru sebagai pendidik, pengajar dan pelatih hendaknya dapat berimbas kepada siswanya. Dalam hal ini guru hendaknya dapat meningkatkan terus kinerjanya yang merupakan modal bagi keberhasilan pendidikan. Kinerja dapat diartikan sebagai "unjuk kerja atau prestasi sesungguhnya yang dicapai seseorang dalam melaksanakan tugas sesuai dengan tanggung jawab yang diberikan kepadanya. ${ }^{24}$ Sedangkan Daft berpendapat bahwa kinerja merupakan kemampuan organisasi untuk mempertahankan tujuannya dengan menggunakan sember daya secara

22 Sutton, R.E, "Teacher Education and Education Self Direction, A Conceptual Analysis And Emprical Investigation", A international Journal of Research and Studies. Volume 50, No. 2. Summer 1980, 29.

23 House, E.R, School Evaluatio, The Politics and Process (California: McCutchman Publishing Corporation. 1973), 51.

${ }^{24}$ Anwar Prabu Mangkunegara, Evaluasi Kinerja Sumber Daya Manusia (Bandung: Refika Aditama 2000), 67. 
efektif dan efisien. ${ }^{25}$ Oleh sebab itu, kinerja guru PAK adalah merupakan prestasi kerja yang dicapai seorang guru PAK dalam melaksanakan tugas-tugas yang dibebankan kepadanya yang didasarkan atas kecakapan, pengalaman, dan kesungguhan. ${ }^{26}$ Dalam hal ini kinerja guru PAK akan baik jika telah melakukan unsur-unsur yang terdiri dari kesetiaan dan komitmen yang tinggi pada tugasnya dalam mendidik dan mengajar PAK. Optimalisasi terhadap penguasaan dan pengembangkan produk-produk pengajaran serta kedisiplinan dalam melaksanaan tugas mengajar dan tugas lainnya, yang disertai dengan berbagai kreativitas diri serta kerjasama dengan semua warga sekolah, dan mampu mewujudkan kepemimpinan yang menjadi panutan bagi siswa, berkepribadian yang baik, jujur dan objektif dalam membimbing siswa, serta tanggung jawab terhadap tugasnya adalah bagian yang tidak dapat dipisahkan dari kinerja guru PAK. $^{27}$ Singkatnya seluruh aspek keberhasilan pendidikan dan pengajaran, baik pada tataran institusional dan eksperiensial, harus dimulai dari aspek "guru" dan tenaga kependidikan lainnya karena menyangkut kualitas keprofesionalannya.

Untuk mengukur kinerja seorang guru PAK, beberapa indikator perlu diperhatikan. Penilaian guru PAK sendiri mengacu kepada instrumen yang ditetapkan oleh Depdiknas yang dikenal dengan Alat Penilaian Kemampuan Guru (APKG) dan di dalamnya unsur-unsur kinerja guru meliputi: rencana pembelajaran (teachingplans and materials); prosedur pembelajaran (classroomprocedure); dan hubungan antar pribadi (interpersonalskill). Karena itu, kinerja guru tercermin dalam beberapa kegiatan guru seperti perencanaan pembelajaran, pelaksanaan pembelajaran/ KBM, dan melakukan evaluasi atau penilaian hasil pembelajaran yang merupakan aktualisasi dari kompetensi guru dan interaksi antara guru dengan siswa. ${ }^{28}$ Hasil pengukuran terhadap ketiga kegiatan tersebut menggambarkan jumlah dan mutu proses dan hasil kerja yang dicapai guru dalam mengajar selama periode waktu tertentu.

${ }^{25}$ Richard L. Daft, Era Baru Manajemen (Jakarta: Salemba Empat, 2010), 24-25.

${ }^{26}$ Malayu S.P. Hasibuan. Manajemen Sumber Daya Manusia (Jakarta : Bumi Aksara, 2001), 94.

${ }^{27}$ Supandi. Administrasi dan Supervisi Pendidikan (Jakarta: Departemen Agama, 1996), 252.

${ }^{28}$ Depdiknas. Dimensi Kompetensi Supervisi Manajerial: Bahan Belajar Mandiri Musyawarah Kerja Pengawas Sekolah (Jakarta: Depdiknas, 2008), 22 -26. 


\section{Bentuk-bentuk Kinerja Guru PAK}

Pertama, merencanakan pembelajaran. Tahap perencanaan dalam kegiatan pembelajaran adalah tahap yang berkaitan dengan kemampuan guru untuk mengelola dan menguasai pembelajaran. Terhadap hal ini kemampuan guru dapat dilihat dari bagaimana seorang guru untuk menyusun berbagai program/ kegiatan pembelajaran, yaitu mengembangkan silabus dan rencana pelaksanaan pembelajaran (RPP). Unsur/komponen yang ada dalam silabus terdiri dari: Penetapan Identitas Silabus; Penetapan Stándar Kompetensi dan Kompetensi Dasar; Pencapaian Indikator Materi Pembelajaran.

Kedua, melaksanakan kegiatan pembelajaran. Kegiatan pembelajaran adalah suatu proses yang mengandung serangkaian kegiatan guru dan siswa atas dasar hubungan timbal balik yang berlangsung dalam situasi edukatif untuk mencapai tujuan tertentu. Winarno menjelaskan bahwa: pembelajaran adalah proses berlangsungnya kegiatan belajar dan membelajarkan siswa di kelas. ${ }^{29}$ Dari definisi tersebut diketahui bahwa dalam proses pembelajaran terjadi proses interaksi yang bersifat edukatif antara guru dengan siswa yang bermuara pada satu tujuan yaitu untuk mencapai tujuan pembelajaran. Efektivitas dan keberhasilan pembelajaran PAK dapat tercapai sangat tergantung dari kemampuan guru PAK untuk mencapai keberhasilan proses pembelajaran tersebut. Dalam pembelajaran di sekolah, terdapat proses belajar, yaitu proses terjadinya perubahan pengetahuan, sikap, informasi, kemampuan dan keterampilan yang sifatnya permanent melalui pengalaman. Jadi, proses pembelajaran adalah merupakan suatu proses yang menjadi inti dari kegiatan transfer of knowledge dan transfer of action dari guru kepada siswa di sekolah. Secara sederhana proses pembelajaran adalah merupakan interaksi antara guru dengan siswa secara langsung dalam kelas, dalam rangka mentransfer ilmu pengetahuan dan tekhnologi dari guru kepada siswa. Kegiatan pembelajaran PAK ditandai oleh adanya kegiatan pengelolaan kelas, penggunaan media dan sumber belajar, dan penggunaan metode serta strategi pembelajaran. Semua tugas tersebut merupakan tugas dan tanggung jawab guru yang secara optimal dalam pelaksanaanya menuntut kemampuan guru PAK.

Ketiga, mengevaluasi hasil pembelajaran. Evaluasi atau penilaian hasil belajar adalah kegiatan atau cara yang ditujukan untuk mengetahui tercapai atau tidaknya tujuan pembelajaran dan juga proses pembelajaran yang telah dilakukan. Pada tahap ini seorang guru dituntut memiliki kemampuan dalam menentukan pendekatan

${ }^{29}$ Winarmo Surakhmad, Metodologi Pengajaran Nasional (Bandung: Jemmars, 1979), 19. 
dan cara-cara evaluasi, penyusunan alat-alat evaluasi, pengolahan, dan penggunaan hasil evaluasi. Pendekatan atau cara yang dapat digunakan untuk melakukan evaluasi/ penilaian hasil belajar adalah melalui Penilaian Acuan Norma (PAN) dan Penilaian Acuan Patokan (PAP). PAN adalah cara penilaian yang tidak selalu tergantung pada jumlah soal yang diberikan atau penilaian dimasudkan untuk mengetahui kedudukan hasil belajar yang dicapai berdasarkan norma kelas. Siswa yang paling besarskor yang didapat di kelasnya, adalah siswa yang memiliki kedudukan tertinggi di kelasnya.

\section{Hipotesis Tindakan}

Sebelum mendapatkan fakta yang benar, seorang peneliti pasti akan mengamati sesuatu gejala, peristiwa, atau masalah yang menjadi focus perhatiannya. Kemudian peneliti akan membuat dugaan tentang gejala, peristiwa, atau masalah yang menjadi titik perhatiannya tersebut. Dugaan tersebut disebut dengan hipotesis. Hipotesis adalah merupakan jawaban sementara dari suatu penelitian yang harus diuji kebenarannya dengan jalan research. ${ }^{30}$ Berdasarkan pendapat tersebut, dengan mengambil contoh dari rumusan masalah dan tujuan penelitian sebelunnya, berikut ini diajukan hipotesistindakan dalam penelitian yaitu: suvervisi akademik individual dapat meningkatkan kinerja guru PAK di SMK Immanuel Medan.

\section{Metode dan Prosedur Penelitian}

Penelitian ini dilaksanakan di SMK Immanuel Medan yang terletak di Jl. Gatot Subroto, Medan, Sumatera Utara dan berlangsung selama semester gasal tahun 2016. Adapun tahapan penelitian ini terdiri dari beberapa tahapan, yakni mulai dari tahapan perencanaan, pelaksanaan, evaluasi dan tahapan refleksi. Berdasarkan tahapan tersebut dapat dipahami bahwa metode yang digunakan dalam penelitian ini adalah metode penelitian tindakan yang menekankan kepada kegiatan (tindakan) dengan mengujicobakan suatu ide ke dalam praktek atau situasi nyata dan diharapkan kegiatan tersebut mampu memperbaiki, meningkatkan kualitas dan melakukan perbaikan. Adapun prosedur penelitian ini digambarkan sebagai berikut:

\section{Rancangan Siklus I}

a. Perencanaan

1) Mempersiapkan lembaran observasi suvervisi individual yang menyangkut waktu, cara mengobservasi, dan sasaran yang

${ }^{30}$ Kartini Kartono, Pengantar Metodologi Sosial (Bandung : Tarsito, 1996), 70. 
akan dicapai dari suvervisi kinerja guru PAK yang akan diobervasi

2) Mempersiapkan jadwal suvervisi individual, baik observasi kelas kunjungan ke kelas maupun kunjungan antar kelas, .

3) Mempersiapkan jadwal pertemuan individual dengan guru PAK yang akan diobervasi.

4) Mempersiapkan lembaran penilaian hasil pascasuvervisi individual.

b. Pelaksanaan

1) Kunjungan Kelas.

Dalam melaksanakan kunjungan kelas, dilakukan dengan beberapa tahapan, yaitu:

a) Mengamati langsung jalannya proses pembelajaran PAK yang sedang berlangsung.

b) Pengawas bersama guru PAK mengadakan perjanjian untuk membicarakan hasil-hasil observasi, setelah itu dilakukan tindak lanjut. Ada beberapa kriteria kunjungan kelas yang baik, yaitu;

(1) Memiliki tujuan-tujuan tertentu.

(2) Mengungkapkan aspek-aspek yang dapat memperbaiki kemampuan guru.

(3) Menggunakan instrument observasi tertentu untuk mendapatkan daya yang obyektif.

(4) Terjadi interaksi antara Pembina dan yang dibina sehingga menimbulkan sikap saling pengertian.

(5) Pelaksanaan kunjungan kelas tidak menganggu proses belajar mengajar.

(6) Pelaksanaannya diikuti dengan program tindak lanjut.

2) Observasi Kelas

Dalam tahapan observasi kelas terdapat beberapa hal yang harus perhatikan oleh pengawas, yaitu:

a) Usaha-usaha dan aktivitas guru-siswa dalam proses pembelajaran.

b) Cara penggunaan media pengajaran.

c) Reaksi mental para siswa dalam proses belajar mengajar.

d) Keadaan media pengajaran yang dipakai dari segi materialnya.

3) Pertemuan Individual

Pertemuan individual merupakan pertemuan, percakapan, dialog, dan tukar pikiran antara supervisor dengan gan guru PAK. Yang dibicarakan dalam hal ini adalah bagaimana meningkatkan kinerja guru PAK, seperti: 
a) Memberikan pemahaman tentang kemungkinan pertumbuhan jabatan guru PAK melalui pemecahan masalah yang dihadapi;

b) Bagaimana mengembangkan hal mengajar yang lebih baik;

c) Cara memperbaiki segala kelemahan dan kekurangan pada diri sendiri; dan

d) menghilangkan atau menghindari segala prasangka yang bukan-bukan tentang hal-hal yang berkaitan dengan jalannya suvervisi tersebut.

4) Kunjungan Antar Kelas

Dalam kegiatan ini yang harus dilakukan adalah guru PAK yang satu berkunjung ke kelas yang lain dalam lingkungan sekolah itu sendiri ketika guru PAK yang lain sedang mengajar. Melalui kunjungan antarkelas ini diharapkan guru PAK akan memperoleh pengalaman baru dari teman sejawatnya mengenai pelaksanaan proses pembelajaran, pengelolaan kelas, dan sebagainya. Oleh sebab itu pengawas perlu memberikan pemahaman berikut:

a) Sesama guru-guru PAK akan saling mengunjungi.

b) Pengawas menyediakan fasilitas yang diperlukan dalam kunjungan kelas.

c) Pengawas selalu mengikuti acara ini mencatat setiap hal-hal yang terjadi pada format yang telah disediakan.

d) Mengadakan tindak lanjut setelah kunjungan antarkelas selesai seperti: percakapan pribadi, penegasan, dan pemberian tugas-tugas tertentu.

e) Memerintahkan agar guru PAK mengaplikasikan hasil-hasil yang dicapai ke sekolah atau ke kelas guru bersangkutan, yaitu dengan menyesuaikan pada situasi dan kondisi yang dihadapi.

c. Pengamatan

Pada tahapan ini dilakukan beberapa hal, yaitu:

1) Pengawas selalu mengamati setiap acara yang berkaitan dengan suvervisi individual yang dilaksanakan, seperti kunjungan kelas, pertemuan individual, dan kunjungan antarkelas.

2) Pengawas harus mencatat setiap hal-hal yang terjadi pada format yang telah disediakan.

d. Refleksi

1) Mengadakan tindak lanjut setelah kunjungan antarkelas selesai seperti: percakapan pribadi, penegasan, dan pemberian tugastugas tertentu.

2) Memerintahkan agar guru PAK mengaplikasikan hasil-hasil yang dicapai ke sekolah atau ke kelas guru bersangkutan, yaitu dengan menyesuaikan pada situasi dan kondisi yang dihadapi. 


\section{Rancangan Siklus II}

\section{a. Perencanaan}

Perencanaan tindakan untuk siklus II didasari dari hasil pelaksanaan siklus I. Jika pada saat pelaksanaan siklus I masih terdapat kelemahan, maka perlu disusun skenario pelaksanaan supervisi individual seperti pada siklus I yang tentunya dengan beberapa perbaikan. Perbaikan-perbaikan tersebut tentunya menyangkut waktu, cara mengobservasi, dan sasaran yang akan dicapai dari suvervisi kinerja guru PAK yang akan diobervasi. Kemudian mengoptimalisasi jadwal suvervisi individual, baik observasi kelas, kunjungan ke kelas maupun kunjungan antar kelas serta jadwal pertemuan individual dengan guru PAK yang akan diobervasi.

b. Pelaksanaan

1) Mengamati langsung jalannya proses pembelajaran PAK yang sedang berlangsung.

2) Membicarakan kembali hal-hal yang berikaitan hasil observasi.

3) Mendisikusikan aspek-aspek yang berikaitan dengan kendala yang dihadapi oleh guru PAK selama proses siklus I sedang berlangsung.

4) Mengidentifikasi kelemahan guru PAK dan cra-cara memperbaiki kemampuan guru.

c. Pengamatan

Memperbaiki teknik dan cara dan teknik observasi yang dilakukan oleh pengawas dalam mengamati setiap acara yang berkaitan dengan suvervisi individual terhadap guru PAK.

d. Refleksi

Mengadakan pertemuan-pertemuan dengan guru PAK sebagai tindak lanjut setelah supervisi individual dilaksanakan serta mendiskusikan bagaimana agar hasil-hasil yang telah dicapai segera diaplikasikan.

\section{Populasi dan Sampel}

Populasi adalah semua elemen yang ada dalam wilayah penelitian. Sedangkan sampel adalah sebagian dari populasi yang diteliti." 31 Yang menjadi sampel dalam penelitian ini adalah keseluruhan guru PAK di SMK Immanuel Medan yang berjumlah 5 orang. Sesuai dengan variabel penelitian teknik suvervisi individual dilaksanakan pada tiap orang guru PAK. 1995), 54.

31 Winarno Surakhmad, Pengantar Penelitian Ilmiah (Bandung Karsito, 
Tabel 1.

Data Guru PAK di SMK Immanuel Medan

\begin{tabular}{|l|l|l|l|l|l|}
\hline NO. & Nama Sekolah & Alamat Sekolah & Nama Guru & $\begin{array}{r}\text { MASA } \\
\text { KERJA }\end{array}$ & L/P \\
\hline 1. & SMK Immanuel & Jl. Gatot Subroto & $\begin{array}{l}\text { Joni } \\
\text { Marbun,S.Th }\end{array}$ & 4 Thn & L \\
\hline 2. & SMK Immanuel & Jl. Gatot Subroto & $\begin{array}{l}\text { Marisa H. Br. } \\
\text { Ginting }\end{array}$ & 3 Thn & $\mathrm{P}$ \\
\hline 3. & SMK Immanuel & Jl. Gatot Subroto & Nurli Silalahi & 10 Thn & $\mathrm{P}$ \\
\hline 4. & SMK Immanuel & Jl. Gatot Subroto & Susanna & $16 \mathrm{Thn}$ & $\mathrm{P}$ \\
\hline 5. & SMK Immanuel & Jl. Gatot Subroto & Rosbina & 4 Thn & $\mathrm{P}$ \\
\hline
\end{tabular}

Sumber: Database SMK Immanuel Medan

\section{Teknik dan Instrumen Pengumpulan Data}

Pengumpulan data merupakan bagian yang terpenting dalam suatu penelitian, bahkan merupakan suatu keharusan bagi seorang peneliti. Untuk mendapatkan data yang diperlukan dalam penelitian. Selanjutnya, instrumen pengumpulan data merupakan alat bantu yang dipilih dan digunakan oleh peneliti dalam kegiatannya mengumpulkan agar kegiatan tersebut menjadi sistematis dan dipermudah olehnya. ${ }^{32}$ Atau dapat juga disebut sebagai alat ukur yang digunakan untuk mendapatkan informasi kuantitatif tentang variasi karakteristik variabel secara objektif. ${ }^{33}$ Berdasarkan pendapat tersebut instrumen yang digunakan penelitian ini instrumen penelitian nyang digunakan untuk mengumpulkan data penelitian adalah dengan melakukan observasi. Observasi merupakan proses melakukan pengamatan secara langsung terhadap suatu objek untuk mengetahui keadaan yang sebenarnya mengenai objek tersebut. Objek yang dimaksud di sini adalah guru-guru PAK di SMK Immanuel Medan.

\section{Indikator Keberhasilan}

Keberhasilan dalam penelitian ini adalah dilihat dari meningkatnya kinerja guru PAK sebagai perencana, pelaksana dan mengevaluasi hasil pembelajaran. Keberhasilan kegiatan suvervisi akademik individual dianggap berhasil apabila seluruh perangkat indikator kinerja guru PAK berada pada kategori Sangat Baik.

${ }^{32}$ Suharsimi Arikunto, Manajemen Penelitian (Jakarta: Rineka Cipta, 2000), 134.

${ }^{33}$ Hadjar, Dasar-dasar Metodologi Penelitian Kuantitatif dalam Pendidikan (Jakarta: Radja Grasifindo, 1996), 160. 
Tabel 2.

Indeks Pencapaian Kinerja Guru PAK

\begin{tabular}{|l|l|l|c|}
\hline \multirow{2}{*}{ No. } & \multirow{2}{*}{$\begin{array}{c}\text { Interval Skor } \\
\text { Pencapaian }\end{array}$} & \multicolumn{2}{|c|}{ Keterangan Skor } \\
\cline { 3 - 4 } & $0-70$ & Sebutan & Kategori \\
\hline & $0-70-79$ & Kurang Baik & \multirow{2}{*}{ Tidak Berhasil } \\
\hline & $80-89$ & Baik & Kurang Berhasil \\
\hline & $90-100$ & Sangat Baik & Berhasil \\
\hline
\end{tabular}

\section{HASIL PENELITIAN}

\section{Hasil Penelitian Pra-observasi}

\section{Deskripsi Awal Tindakan}

Sebelum melakukan tindakan supervisi individual ini peneliti benar-benar mempersiapkan berbagai perangkan yang dibutuhkan selama kegiatan berlangsung. Oleh sebab itu peneliti harus mempersiapkan diri dalam menguasai teknik suvervisi individual secara matang mulaia penyediaan lembar observasi, bagaimana teknik supervisi, solusi yang akan ditawarkan (tindak lanjut), dan juga harus menguasai kemungkinan kendala-kendala yang akan dihadapi selama di lapangan, mulai dari waktu, biaya, sasaran dan kondisi guru dan sekolah yang sedang disupervisi.

Dalam kegiatan kunjungan dan pembicaraan dengan pihak kepala sekolah, serta pengamatan langsung ke kelas guru-guru PAK, kemudian menganalisis beberapa perangkat kinerja guru, terlihat bahwa kinerja guru PAK di SMK Immanuel Medan belum maksimal sebagaimana yang diharapkan, baik oleh sekolah maupun dari pihak peneliti sendiri. Terdapat beberapa hal yag menjadi penyebabnya, yakni: kurangnya pemahaman dalam membuat perangkat ajar (sebagai akibat dari perubahan kurikulum dan kurangnya waktu guru dalam mengikuti pelatihan penyusunan perangkat ajar), masih terbatasnya fasilitas ajar. Kurangya pemahaman dalam menentukan instrumen penilaian dan lain sebagainya. Oleh sebab itu keadaan ini harus segera ditindaklanjuti bagaimana cara mengatasinya. 


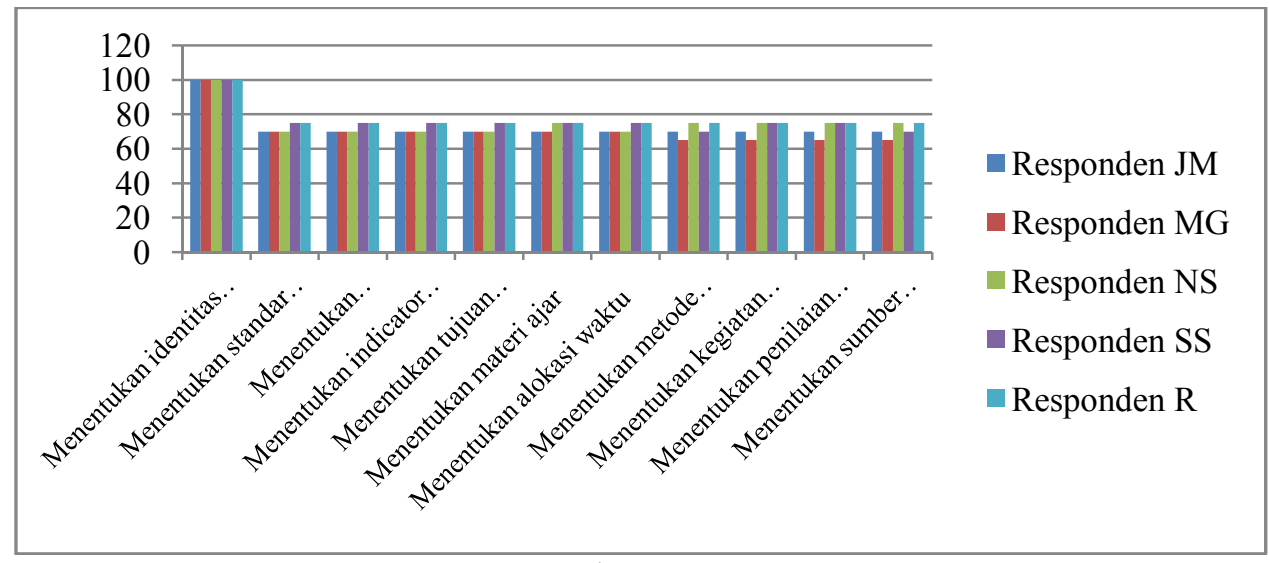

Gambar. 1

Histogram sebaran Indikator Kinerja Guru dalam Merencanakan Pembelajaran

Deskripsi Hasil Observasi Awal

Tabel 3.

Pengamatan Indeks Kinerja Guru PAK Secara Kumulatif PraObservasi di SMK Immanuel Medan

\begin{tabular}{|c|c|c|c|c|c|c|}
\hline \multirow{2}{*}{ No } & \multirow{2}{*}{$\begin{array}{c}\text { Respond } \\
\text { en }\end{array}$} & $\begin{array}{c}\text { Merencanakan } \\
\text { Pemb. PAK }\end{array}$ & $\begin{array}{c}\text { Melaksa- } \\
\text { nakan Pemb. } \\
\text { PAK }\end{array}$ & $\begin{array}{c}\text { Mengevalu- } \\
\text { asi Pemb. } \\
\text { PAK }\end{array}$ & Rerata & Kategori \\
\hline 1. & JM & 72.7 & 69.6 & 68.3 & 70.2 & Cukup Baik \\
\hline 2. & MG & 71 & 67 & 64 & 67 & Cukup Baik \\
\hline 3. & NS & 75 & 76.8 & 71.7 & 74.5 & Cukup Baik \\
\hline 4. & SS & 76.4 & 68.5 & 65.8 & 70.2 & Cukup Baik \\
\hline 5. & R & 77.3 & 69.6 & 65 & 70.6 & Cukup Baik \\
\hline
\end{tabular}

Pada tabel pengamatan indeks Kinerja Guru PAK Secara Kumulatif Pra-Observasi di SMK Immanuel Medan di atas peneliti terlihat beberapa hal tentang guru-guru yang menjadi responden dalam penelitian ini, yakni: bahwa rata -rata nilai indeks kinerja yang diperlihatkan oleh guru PAK pada kategori Cukup Baik sehingga dalam catatan peneliti hal ini membutuhkan upaya perbaikan segera.

\section{Hasil Penelitian Tindakan Siklus I}

a. Perencanaan Kegiatan Siklus I

Kegiatan perencanaan dimulai setelah mencermati hasil ratarata perolehan skor pengamatan tentang kinerja guru di SMK Immanuel Medan. Kegiatan ini didasarkan pada catatan peneliti bahwa kinerja guru PAK di sekolah ini perlu mendapatkan perhatian peningkatan. Tahapan perencanaan diawali dengan mempersiapkan 
seluruh lembaran observasi tentang suvervisi individual yang akan dilakukan peneliti yang beriksikan hal-hal yang menyangkut waktu, cara mengobservasi, dan sasaran yang akan dicapai dari suvervisi kinerja guru PAK yang akan diobervasi. Setelah itu dilanjutkan dengan mempersiapkan jadwal pelaksanaan suvervisi individual, baik observasi kelas kunjungan ke kelas maupun kunjungan antar kelas; serta mempersiapkan jadwal pertemuan individual dengan guru PAK yang akan diobervasi. Dan tidak lupa juga bahwa peneliti menyediakan lembaran penilaian hasil pasca pelaksanaan suvervisi individual yang dilakukan oleh peneliti terhadap guru-guru PAK di SMK Immanuel Medan. Sebagai tambahan bahwa dalam tahapan perencanaan ini, para guru-guru PAK tidak mendapatkan gambaran waktu mengenai pelaksanaan supervisi dimaksud. Akan tetapi dalam perenaan ini peneliti memberikan rentang waktu untuk pelaksanaan siklus I selama 3 (tiga) minggu.

b. Pelaksanaan Kegiatan Siklus I

Kegiatan suvervisi individual dilaksanakan selama tiga minggu mulai dan dilaksanakan setiap harinya. Akan tetapi dalam pelaksanaannya peneliti tidak memberitahukan kepada guru-guru PAK mengenai kapan dan siapa yang akan disuvervisi. Hal itu dimaksudkan agar peneliti memperoleh gambaran yang jelas apakah tindakan ini dapat membuat guru-guru PAK untuk meningkatkan kinerjanya. Artinya tindakan ini dilakukan tanpa membuat jadwal dan suasana pembelajaran terganggu. Peneliti berusaha untuk membuat proses suvervisi ini berjalan secara alamiah. Dalam tahapan ini yang dilakukan adalah kunjungan dan observasi kelas, berbincang-bincang dengan guru-guru PAK secara acak, kemudian bersama dengan guru PAK peneliti mengamati guru PAK yang lain secara langsung tanpa mengintervensi suasana pembelajaran yang sedang terjadi. Seluruh rangkaian proses ini dicatat dalam lembar observasi dan penilaian yang telah dipersiapkan sebelumnya.

c. Pengamatan

Setelah waktu pelaksanaan suvervisi selesai sesuai dengan waktu yang telah ditetapkan, kemudian peneliti merekapitulasi hasil pengamatan yang telah dilakukan selama masa pelaksanaan supervisi. Berdasarkan hasil pengamatan yang telah dilakukan, hasil kinerja yang telah dicapai oleh guru PAK kemudian ditabulasi sebagaimana terlihat dalam tabel berikut: 
Tabel 4.

Hasil Pengamatan Kegiatan Siklus I

\begin{tabular}{|c|c|c|c|c|c|c|c|}
\hline \multirow[t]{2}{*}{ No. } & \multirow{2}{*}{\multicolumn{2}{|c|}{$\begin{array}{l}\text { Uraian Kegiatan dan Aspek- } \\
\text { aspeknya }\end{array}$}} & \multicolumn{5}{|c|}{$\begin{array}{l}\text { Nilai Pengamatan Tiap } \\
\text { Responden }\end{array}$} \\
\hline & & & $\mathrm{JM}$ & MG & NS & SS & $\mathrm{R}$ \\
\hline \multirow[t]{13}{*}{ I. } & \multicolumn{7}{|c|}{ Merencanakan Pembelajaran } \\
\hline & 1. & $\begin{array}{l}\text { Menentukan identitas mata } \\
\text { pelajaran }\end{array}$ & 100 & 100 & 100 & 100 & 100 \\
\hline & 2. & $\begin{array}{l}\text { Menentukan standar } \\
\text { kompetensi }\end{array}$ & 80 & 75 & 80 & 80 & 90 \\
\hline & 3. & $\begin{array}{l}\text { Menentukan kompetensi } \\
\text { dasar }\end{array}$ & 85 & 75 & 85 & 80 & 80 \\
\hline & 4. & $\begin{array}{l}\text { Menentukan indicator } \\
\text { pencapaian kompetensi }\end{array}$ & 80 & 75 & 85 & 80 & 90 \\
\hline & 5. & $\begin{array}{l}\text { Menentukan tujuan } \\
\text { pembelajaran }\end{array}$ & 80 & 75 & 85 & 80 & 90 \\
\hline & 6. & Menentukan materi ajar & 80 & 75 & 90 & 90 & 90 \\
\hline & 7. & Menentukan alokasi waktu & 90 & 80 & 75 & 86 & 85 \\
\hline & 8. & $\begin{array}{l}\text { Menentukan metode } \\
\text { pembelajaran }\end{array}$ & 85 & 80 & 75 & 80 & 85 \\
\hline & 9. & $\begin{array}{l}\text { Menentukan kegiatan } \\
\text { pembelajaran }\end{array}$ & 80 & 75 & 80 & 80 & 80 \\
\hline & 10. & $\begin{array}{l}\text { Menentukan penilaian hasil } \\
\text { belajar }\end{array}$ & 70 & 75 & 80 & 75 & 80 \\
\hline & 11. & Menentukan sumber belajar & 75 & 75 & 85 & 75 & 85 \\
\hline & & Rata-rata 1 & 82,3 & 78 & 83,6 & 82,4 & 86,8 \\
\hline II. & \multicolumn{7}{|c|}{ Melaksanakan Pembelajaran } \\
\hline & 1. & $\begin{array}{l}\text { Menjelaskan tujuan dan } \\
\text { kompetensi dasar }\end{array}$ & 80 & 85 & 85 & 80 & 80 \\
\hline & 2. & $\begin{array}{l}\text { Menyampaikan cakupan } \\
\text { materi dan uraian kegiatan } \\
\text { sesuai dengan silabus }\end{array}$ & 80 & 85 & 85 & 85 & 85 \\
\hline & 3. & $\begin{array}{l}\text { Menjelaskan isi kegiatan } \\
\text { kepada siswa/langkah } \\
\text { kegiatan }\end{array}$ & 70 & 70 & 80 & 65 & 90 \\
\hline & 4. & $\begin{array}{l}\text { Menggunakan ekspresi } \\
\text { dalam berkomunikasi } \\
\text { dengan siswa }\end{array}$ & 85 & 85 & 80 & 80 & 80 \\
\hline & 5. & $\begin{array}{l}\text { Menggunakan respon siswa } \\
\text { dalam menyelenggarakan } \\
\text { kegiatan }\end{array}$ & 80 & 75 & 80 & 80 & 75 \\
\hline & 6. & $\begin{array}{l}\text { Menggunakan media dan } \\
\text { alat pembelajaran yang } \\
\text { sesuai dengan tujuan }\end{array}$ & 75 & 75 & 85 & 85 & 75 \\
\hline & 7. & $\begin{array}{l}\text { Menyelenggarakan } \\
\text { kegiatan dengan urutan } \\
\text { yang logis }\end{array}$ & 80 & 70 & 75 & 75 & 80 \\
\hline & 8. & $\begin{array}{l}\text { Menggunakan berbagai } \\
\text { metode dalam menjelaskan }\end{array}$ & 80 & 75 & 75 & 75 & 80 \\
\hline
\end{tabular}




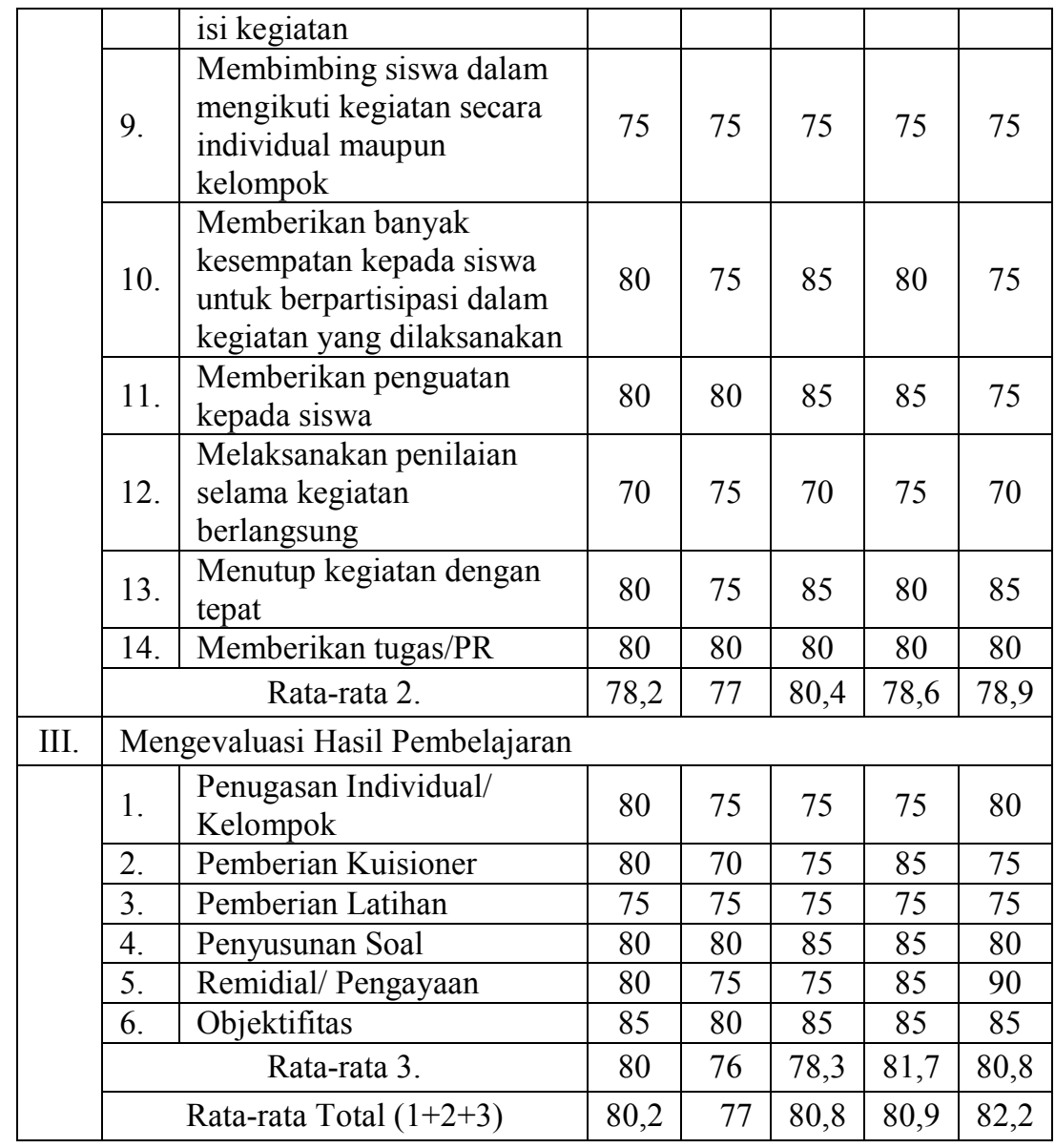

d. Refleksi Kegiatan Siklus I

Berdasarkan hasil dan analisis terhadap kinerja yang dilakukan oleh guru-guru PAK, dan untuk mengetahui tingkat perkembangan dan kekurangan yang dimiliki oleh guru PAK, maka hasil pengamatan terhadap kinerja guru PAK disajikan satu persatu dalam bentuk histogram .

1) Kinerja guru PAK dalam merencanakan pembelajaran. Berdasarkan histogram pengamatan, terlihat bahwa rata-rata pencapaian kinerja yang ditunjukkan oleh guru PAK selama tindakan siklus I semuanya mengalami peerkembangan. Adapun rentang rata-rata pencapaian kinerja tersebut terdiri dari skor terendah 72, 18 dan skor tertinggi terdiri dari 86.82.

2) Kinerja guru PAK dalam melaksanakan pembelajaran. Histogram pengamatan menunjukkan bahwa rentang skor pencapaian nilai pelaksanaan pembelajaran PAK berada pada angka tertinggi sebesar 80.36 dan skor terendah pada kisaran 77.14 .

3) Kinerja guru PAK dalam mengevaluasi hasil pembelajaran. Histogram pengamatan menunjukkan bahwa rentang skor 
pencapaian nilai kinerja guru dalam mengevaluasi pembelajaran PAK berada pada skor tertinggi 82.19 dan skor terendah pada kisaran 77.05.

Dari hasil pengamatan pada ketiga indikator kinerja guru PAK tersebut peneliti merefleksikan bahwa sebenarnya kinerja guru PAK dapat ditingkatkan. Memang ada yang menunjukkan perkembangan secara cepat, namun ada juga guru yang memiliki kesulitan dalam mengimplementasikan maksud suvervisi ini terhadap kinerjanya. Berdasarkan komunikasi yang dilakukan dpat diketahui bahwa hal ini disebabkan bahwa intensitas suvervisi yang dilakukan oleh peneliti adalah hal yang tidak biasanya terjadi. Para guru-guru PAK awalnya menganggap bahwa kunjungan tersebut adalah kunjungan biasa. Sehingga guru beranggapan bahwa dalam suvervisi kali ini pengamatan tidak dilakukan secara individual. Akan tetapi karena peneliti kemudian melakukan suvervisi secara individual secara optimal dan lebih dari biasanya, barulah kemudian guru PAK mulai mengetahui bahwa mereka sedang di suvervisi. Apalagi ketika peneliti mengumpulkan semua dokumen yang berkaitan dengan perangkat kinerjanya sebagai guru PAK per-pertemuan di kelas, barulah para guru merasakan bahwa hal ini adalah metode suvervisi yang baru di lakukan. Oleh sebab itu sebagian guru ada yang langsung memperbaiki unsur-unsur kinerjanya secara cepat. Tetapi masih ditemukan bahwa masih terdapat guru yang merubah kinerjanya secara perlahan-lahan. Hal itu dapat dipahami sebagai akibat dari suvervisi yang dilakukan secara individual dianggap masih baru oleh guru tersebut.

\section{Hasil Penelitian Tindakan Siklus II}

a. Perencanaan Kegiatan Siklus II

Dengan mencermati hasil pada siklus I, maka peneliti mengajak semua reponden untuk kembali melakukan pertemuan lanjutan. Pertemuan lanjutan ini dimaksudkan agar responden semakin merasa terbiasa dengan kegiatan ini. Secara keseluruhan, hasil pengamatan terhadap kinerja pada Siklus I sudah mengalami peningkatan, yakni pada kategori Baik. Akan tetapi peneliti melihat bahwa hasil ini kurang dianggap sebagai indikator keberhasilan suvervisi individual tersebut. Kemudian, dengan adanya gejala perbaikan kinerja pada siklus I ini, peneliti memiliki optimisme bahwa bila kegiatan tersebut dilanjutkan akan berdampak pada peningkatan kinerja yang dilakukan oleh guru PAK secara maksimal. Oleh sebab itu maka tindakan siklus II perlu dilaksanakan. Dalam perencanaan kegiatan tindakan Siklus II ini konsep dan cara kerja tetap mengacu 
kepada cara kerja suvervisi individual yang telah terlaksana pada siklus sebelumnya.

b. Pelaksanaan Kegiatan Siklus II

Pelaksanaan tindakan siklus II ini juga berlangsung selama tiga minggu. Pelaksanaannya tidak jauh berbeda dengan tindakan siklus I. Hanya suvervisi individual pada tindakan siklus II ini lebih difokuskan kepada hal-hal yang menyangkut obervasi dan kunjungan kelas/ antarkelas, serta pertemuan individual yang dilakukan oleh peneliti dengan guru-guru PAK di SMK Immanuel. Hal itu disebabkan bahwa pembuatan lembaran observasi dan lembaran penilaian observasi dianggap tidak ada masalah.

c. Pengamatan Kegiatan Siklus II

Setelah waktu pelaksanaan suvervisi individual dilakukan, kemudian peneliti melanjutkan pada tahap kegiatan merekapitulasi hasil pengamatan yang telah dilakukan selama masa pelaksanaan supervisi individual siklus II. Berdasarkan hasil pengamatan yang telah dilakukan, hasil kinerja yang telah dicapai oleh guru PAK kemudian ditabulasi sebagaimana terlihat dalam tabel berikut:

Tabel 5.

Hasil Pengamatan Kegiatan Siklus II

\begin{tabular}{|c|c|c|c|c|c|c|c|}
\hline \multirow[t]{2}{*}{ No. } & \multirow{2}{*}{\multicolumn{2}{|c|}{ Uraian Kegiatan dan Aspek-aspeknya }} & \multicolumn{5}{|c|}{$\begin{array}{c}\text { Nilai Pengamatan Tiap } \\
\text { Responden }\end{array}$} \\
\hline & & & $\mathrm{JM}$ & MG & NS & SS & $\mathrm{R}$ \\
\hline \multirow[t]{13}{*}{ I. } & \multicolumn{7}{|c|}{ Merencanakan Pembelajaran } \\
\hline & 1. & Menentukan identitas mata pelajaran & 100 & 100 & 100 & 100 & 100 \\
\hline & 2. & Menentukan standar kompetensi & 90 & 90 & 95 & 95 & 100 \\
\hline & 3. & Menentukan kompetensi dasar & 95 & 95 & 95 & 95 & 95 \\
\hline & 4. & $\begin{array}{l}\text { Menentukan indikator pencapaian } \\
\text { kompetensi }\end{array}$ & 95 & 85 & 95 & 85 & 95 \\
\hline & 5. & Menentukan tujuan pembelajaran & 90 & 90 & 90 & 90 & 95 \\
\hline & 6. & Menentukan materi ajar & 95 & 95 & 95 & 95 & 95 \\
\hline & 7. & Menentukan alokasi waktu & 95 & 95 & 95 & 95 & 95 \\
\hline & 8. & Menentukan metode pembelajaran & 90 & 80 & 95 & 95 & 95 \\
\hline & 9. & Menentukan kegiatan pembelajaran & 95 & 85 & 95 & 95 & 95 \\
\hline & 10. & Menentukan penilaian hasil belajar & 85 & 85 & 85 & 85 & 90 \\
\hline & 11. & Menentukan sumber belajar & 90 & 90 & 90 & 90 & 90 \\
\hline & & Rata-rata 1. & 92,7 & 90 & 93,6 & 92,7 & 95 \\
\hline \multirow[t]{3}{*}{ II. } & \multicolumn{7}{|c|}{ Melaksanakan Pembelajaran } \\
\hline & 1. & $\begin{array}{l}\text { Menjelaskan tujuan dan kompetensi } \\
\text { dasar }\end{array}$ & 95 & 95 & 95 & 95 & 95 \\
\hline & 2. & Menyampaikan cakupan materi dan & 90 & 90 & 90 & 90 & 90 \\
\hline
\end{tabular}




\begin{tabular}{|c|c|c|c|c|c|c|c|}
\hline & & uraian kegiatan sesuai dengan silabus & & & & & \\
\hline & 3. & $\begin{array}{l}\text { Menjelaskan isi kegiatan kepada } \\
\text { siswa/langkah kegiatan }\end{array}$ & 80 & 80 & 95 & 85 & 95 \\
\hline & 4. & $\begin{array}{l}\text { Menggunakan ekspresi dalam } \\
\text { berkomunikasi dengan siswa }\end{array}$ & 90 & 90 & 90 & 90 & 90 \\
\hline & 5. & $\begin{array}{l}\text { Menggunakan respon siswa dalam } \\
\text { menyelenggarakan kegiatan }\end{array}$ & 90 & 85 & 95 & 90 & 95 \\
\hline & 6. & $\begin{array}{l}\text { Menggunakan media dan alat } \\
\text { pembelajaran yang sesuai dengan } \\
\text { tujuan }\end{array}$ & 85 & 85 & 95 & 85 & 90 \\
\hline & 7. & $\begin{array}{l}\text { Menyelenggarakan kegiatan dengan } \\
\text { urutan yang logis }\end{array}$ & 90 & 80 & 95 & 95 & 95 \\
\hline & 8. & $\begin{array}{l}\text { Menggunakan berbagai metode dalam } \\
\text { menjelaskan isi kegiatan }\end{array}$ & 90 & 90 & 90 & 90 & 90 \\
\hline & 9. & $\begin{array}{l}\text { Membimbing siswa dalam mengikuti } \\
\text { kegiatan secara individual maupun } \\
\text { kelompok }\end{array}$ & 85 & 85 & 85 & 85 & 85 \\
\hline & 10. & $\begin{array}{l}\text { Memberikan banyak kesempatan } \\
\text { kepada siswa untuk berpartisipasi } \\
\text { dalam kegiatan yang dilaksanakan }\end{array}$ & 90 & 95 & 85 & 95 & 85 \\
\hline & 11. & Memberikan penguatan kepada siswa & 90 & 80 & 85 & 95 & 95 \\
\hline & 12. & $\begin{array}{l}\text { Melaksanakan penilaian selama } \\
\text { kegiatan berlangsung }\end{array}$ & 80 & 80 & 80 & 80 & 80 \\
\hline & 13. & Menutup kegiatan dengan tepat & 95 & 95 & 95 & 95 & 95 \\
\hline & 14. & Memberikan tugas/PR & 85 & 80 & 85 & 80 & 80 \\
\hline & & Rata-rata 2. & 88,2 & 86 & 90 & 89,3 & 90 \\
\hline III. & Mer & gevaluasi Hasil Pembelajaran & & & & & \\
\hline & 1. & Penugasan Individual/ Kelompok & 80 & 85 & 75 & 80 & 80 \\
\hline & 2. & Pemberian Kuisioner & 80 & 80 & 95 & 85 & 75 \\
\hline & 3. & Pemberian Latihan & 85 & 75 & 85 & 90 & 90 \\
\hline & 4. & Penyusunan Soal & 95 & 90 & 95 & 95 & 95 \\
\hline & 5. & Remidial/ Pengayaan & 80 & 75 & 85 & 85 & 95 \\
\hline & 6. & Objektifitas & 95 & 95 & 95 & 95 & 95 \\
\hline & & Rata-rata 3. & 85,8 & 83 & 88,3 & 88,3 & 88,3 \\
\hline & & Rata-rata Total $(1+2+3)$ & 88,9 & 87 & 90,7 & 90,1 & 91,1 \\
\hline
\end{tabular}

\section{d. Refleksi Kegiatan Siklus II}

Berdasarkan hasil dan analisis terhadap kinerja yang dilakukan oleh guru-guru PAK, dan untuk mengetahui tingkat perkembangan dan kekurangan yang dimiliki oleh guru PAK pada tindakan siklus II, maka hasil pengamatan terhadap kinerja guru PAK disajikan satu persatu dalam bentuk histogram .

1) Kinerja guru PAK dalam merencanakan pembelajaran. Berdasarkan histogram pengamatan, terlihat bahwa rata-rata pencapaian kinerja yang ditunjukkan oleh guru PAK selama tindakan siklus II semuanya mengalami perkembangan. Hal 
itu terlihat dari rata-rata pencapaian nilai kinerja tersebut dari skor terendah 90.00 dan skor tertinggi terdiri dari 95.00.

2) Kinerja guru PAK dalam melaksanakan pembelajaran. Histogram pengamatan menunjukkan bahwa rentang skor pencapaian nilai pelaksanaan pembelajaran PAK berada pada angka tertinggi sebesar 90.00 dan skor terendah pada kisaran 86.43 .

3) Kinerja guru PAK dalam mengevaluasi pembelajaran.Histogram pengamatan menunjukkan bahwa rentang skor pencapaian nilai kinerja guru dalam mengevaluasi pembelajaran PAK berada pada skor tertinggi 91.11 dan skor terendah pada kisaran 86.59 .

\section{Pembahasan}

\section{Pra-observasi Hingga Tindakan Siklus I}

Dari hasil pengamatan dari pra-observasi sampai pelaksanaan tindakan siklus I terjadi peningkatan kinerja guru-guru PAK di SMK Immanuel Medan. Pada pengamatan pra-observasi kinerja guru PAK keseluruhan indikator menunjukkan nilai pada kategori cukup baik. Sedangkan pada tindakan siklus I indikator kinerja guru PAK menunjukkan peningkatan. Pada indikator merencanakan pembelajaran, dari yang sebelumnya kategori cukup baik meningkat menjadi baik (empat orang) dan satu orang tidak mengalami perubahan. Pada indikator melaksanakan pembelajaran, dari yang sebelumnya berada kategori cukup baik, berubah meningkat menjadi baik (1 orang) dan empat orang tidak mengalami perubahan. Sedangkan pada indikator mengevaluasi pembelajaran, dari yang sebelumnya berada kategori cukup baik, berubah meningkat menjadi baik (4 orang) dan 1 orang tidak mengalami perubahan.

Tabel 6.

Hasil Pengamatan Kinerja Guru PAK dari Pra-suvervisi hingga Tindakan Siklus I

\begin{tabular}{|l|l|c|c|c|c|c|}
\hline \multirow{2}{*}{$\begin{array}{l}\text { Kinerja Guru } \\
\text { PAK }\end{array}$} & \multirow{2}{*}{$\begin{array}{l}\text { Rentang } \\
\text { Waktu }\end{array}$} & \multicolumn{6}{|c|}{$\begin{array}{c}\text { Kurail Pengamatan Kinerja Guru PAK dari Pra- } \\
\text { Baik }\end{array}$} & $\begin{array}{c}\text { Cukup } \\
\text { Baik }\end{array}$ & Baik & $\begin{array}{c}\text { Sangat } \\
\text { Baik }\end{array}$ & Jumlah \\
\cline { 2 - 7 } $\begin{array}{l}\text { Merencanakan } \\
\text { Pembelajaran }\end{array}$ & $\begin{array}{l}\text { Pra- } \\
\text { Suvervisi }\end{array}$ & - & 5 orang & - & - & 5 orang \\
\cline { 2 - 7 } & Siklus I & - & 1 orang & 4 orang & - & 5 orang \\
\hline $\begin{array}{l}\text { Melaksanakan } \\
\text { Pembelajaran }\end{array}$ & $\begin{array}{l}\text { Pra- } \\
\text { Suvervisi }\end{array}$ & - & 5 orang & - & - & 5 orang \\
\cline { 2 - 7 } & Siklus I & - & 4 orang & 1 orang & - & 5 orang \\
\hline $\begin{array}{l}\text { Mengevaluasi } \\
\text { Pembelajaran }\end{array}$ & $\begin{array}{l}\text { Pra- } \\
\text { Suvervisi }\end{array}$ & - & 5 orang & - & - & 5 orang \\
\cline { 2 - 8 } & Siklus I & - & 1 orang & 4 orang & - & 5 orang \\
\hline
\end{tabular}




\section{Siklus I Hingga Tindakan Siklus II}

Dari hasil pengamatan dari siklus I hingga siklus II juga semakin mengalami peningkatan. Pada siklus I, seluruh orang responden semua memiliki rata -rata memiliki nilai pada kategori Baik pada seluruh indikator; sedangkan setelah dilakukan tindakan pada siklus II hasilnya menjadi "bahwa keseluruhan indikator kinerja guru PAK, yakni merencanakan, melaksanakan dan mengevaluasi pembelajaran, rata-rata berada berada pada kategori sangat baik. Oleh sebab itu pada siklus II ini tindakan suvervisi secara indivual dianggap telah berhasil karena terjadinya peningkatan kinerja guru-guru PAK berdasarkan hasil pengamatan yang telah dilakukan selama suvervisi. Meskipun beberapa indikator masih menunjukkan nilai pada kategori baik, akan tetapi keseluruhan tindakan ini dianggap telah mencapai indikator keberhasilan tindakan yang telah ditetapkan.

Tabel 7.

Hasil Pengamatan Kinerja Guru PAK Selama Tindakan Siklus I hingga Tindakan Siklus II

\begin{tabular}{|l|l|c|c|c|c|c|}
\hline \multirow{2}{*}{$\begin{array}{l}\text { Kinerja Guru } \\
\text { PAK }\end{array}$} & \multirow{2}{*}{$\begin{array}{l}\text { Rentang } \\
\text { Waktu }\end{array}$} & \multicolumn{5}{|c|}{$\begin{array}{c}\text { Hasil Pengamatan Kinerja Guru PAK Selama } \\
\text { Tindakan Siklus I Hingga Tindakan Siklus II }\end{array}$} \\
\cline { 3 - 7 } & $\begin{array}{c}\text { Kurang } \\
\text { Baik }\end{array}$ & $\begin{array}{c}\text { Cukup } \\
\text { Baik }\end{array}$ & Baik & $\begin{array}{c}\text { Sangat } \\
\text { Baik }\end{array}$ & Jumlah \\
\hline $\begin{array}{l}\text { Merencanakan } \\
\text { Pembelajaran }\end{array}$ & Siklus I & - & 1 orang & 4 orang & - & 5 orang \\
\cline { 2 - 7 } $\begin{array}{l}\text { Melaksanakan } \\
\text { Pembelajaran }\end{array}$ & Siklus II & - & - & - & 5 orang & 5 orang \\
\cline { 2 - 7 } & Siklus I & - & 4 orang & 1 orang & & 5 orang \\
\hline $\begin{array}{l}\text { Mengevaluasi } \\
\text { Pembelajaran }\end{array}$ & Siklus I & - & - & 3 orang & 2 orang & 5 orang \\
\cline { 2 - 7 } & Siklus II & - & 5 orang & - & - & 5 orang \\
\hline
\end{tabular}

\section{PENUTUP}

Berdasarkan seluruh rangkaian penelitian yang telah dilaksanakan disimpulkan bahwa: 1) Pada pengamatan pra-observasi hingga tindakan siklus I indikator kinerja guru PAK dalam merencanakan pembelajaran, dari yang sebelumnya kategori cukup baik meningkat menjadi baik (empat orang) dan satu orang tidak mengalami perubahan. Sedang pada indikator melaksanakan pembelajaran, dari yang sebelumnya berada kategori cukup baik, berubah meningkat menjadi baik (1 orang). Demikian juga pada indikator mengevaluasi pembelajaran, dari yang sebelumnya berada kategori cukup baik, berubah meningkat menjadi baik (4 orang) dan 1 orang tidak mengalami perubahan; 2) Dari hasil pengamatan dari siklus I hingga siklus II juga semakin mengalami peningkatan. Pada siklus I, seluruh orang responden semua memiliki rata -rata memiliki 
nilai pada kategori Baik pada seluruh indikator; sedangkan setelah dilakukan tindakan pada siklus II hasilnya menjadi "bahwa keseluruhan indikator kinerja guru PAK, yakni merencanakan, melaksanakan dan mengevaluasi pembelajaran, rata-rata berada berada pada kategori sangat baik; dan 3) Dari pra-observasi hingga pada tindakan siklus II tindakan suvervisi secara indivual dianggap telah berhasil karena terjadinya peningkatan kinerja guru-guru PAK berdasarkan hasil pengamatan yang telah dilakukan selama suvervisi.

Dengan demikian peneliti menyarankan kepada setiap pengawas PAK agar disarankan agar intensitas tindakan suvervisi ini semakin ditingkatkan.Di samping tindakan observasi dan kunjungan kelas, pertemuan individual dengan guru PAK perlu diperhatikan. Oleh sebab itu guru-guru PAK diharapkan agar memanfaatkan pertemuan ini dengan sebaik-baiknya. Dan yangh terakhir, tindak lanjut yang dihasilkan dari suvervisi individual ini sebaiknya dapat dirumuskan dengan baik agar implementasi yang sesuai dengan kondisi dan keadaan sekolah dapat segera dilaksanakan.

\section{Daftar Pustaka}

Amiruddin dkk, 2006. Manajemen Pengawasan Pendidikan, Jakarta: Quantum Teaching.

Anwar Prabu Mangkunegara, 2000. Evaluasi Kinerja Sumber Daya Manusia, Bandung: Refika Aditama .

B. Suryosubroto, dkk, 2000. Manajemen Tenaga Pendidikan, Yogyakarta: FIP UNY.

Bachtiar Hasan, 2004. Perencanaan Pengajaran Bidang Study, Bandung: Pustaka Ramadhan.

Depdiknas, 2008. Buku Penilaian Kinerja Guru, Jakarta: Departemen Pendidikan Nasional.

Depdiknas, 2008. Dimensi Kompetensi Supervisi Manajerial, Jakarta: Depdiknas.

E.G. Homrighausen dan I.H. Enklaar, 1985. Pendidikan Agama Kristen, Jakarta: BPK Gunung Mulia.

Hadjar, 1996. Dasar-dasar Metodologi Penelitian Kuantitatif dalam Pendidikan, Jakarta: Radja Grasifindo.

Kartini Kartono, 1996. Pengantar Metodologi Sosial, Bandung : Tarsito.

Mahmudi, 2007. Manajemen Kinerja Sektor Publik, Yogyakarta: Unit Penerbit dan Percetakan. Sekolah Tinggi Ilmu Manajemen YKPN.

Malayu S.P. Hasibuan, 2001. Manajemen Sumber Daya Manusia, Jakarta: Bumi Aksara. 
Nana Sudjana, 2006. Standar Mutu Pengawas. Jakarta: Depdiknas.

P.A. Sahertian, 2008. Konsep Dasar \& Teknik Supervisi Pendidikan Dalam Rangka Pengembangan Sumber Daya Manusia, Jakarta: Rineka Cipta.

Richard L. Daft, 2010. Era Baru Manajemen, Jakarta: Salemba Empat.

Ruth Kadarmanto, 1999. Tuntunlah Ke Jalan Yang Benar, Jakarta: BPK. Gunung Mulia.

Sedarmayanti, 2001. Manajemen Sumber Daya Manusia, Bandung: Refika Aditama.

Sri Banun Muslim, 2009. Supervisi Pendidikan Meningkatkan Kualitas Profesionalisme Guru. Bandung: Alfabeta.

Stephen P. Robbin, 1996. Perilaku Organisasi, Jakarta: Indeks.

Suharsimi Arikunto, 2000. Manajemen Penelitian, Jakarta: Rineka Cipta. , 2006. Dasar-dasar Supervisi, Jakarta: Rineka Cipta.

Supandi, 1996. Administrasi dan Supervisi Pendidikan. Jakarta: Departemen Agama.

Wina Sanjaya, 2005. Strategi Pembelajaran Berorientasi Standar Proses Pendidikan, Jakarta: Kencana Prenada Media. 